\title{
Os Conselhos Nacionais de Justiça e do Ministério Público no Brasil: instrumentos de accountability?
}

\author{
Fábio Kerche ${ }^{1}$ \\ Vanessa Elias de Oliveira ${ }^{2}$ \\ Cláudio Gonçalves Couto ${ }^{3}$ \\ 1 Fundação Casa de Rui Barbosa, Rio de Janeiro / RJ - Brasil \\ 2 Universidade Federal do ABC, São Paulo / SP - Brasil \\ 3 Fundação Getulio Vargas / Escola de Administração de Empresas de São Paulo, São Paulo / SP - Brasil
}

Em democracias, conselhos, órgãos colegiados atuantes no Sistema de Justiça possuem diferentes finalidades: reforçar a independência do Poder Judiciário e do Ministério Público (MP), incrementar a accountability em relação a juízes e promotores e/ou aprimorar a gestão da Justiça. Este artigo analisa o Conselho Nacional de Justiça (CNJ) e o Conselho Nacional do Ministério Público (CNMP), considerando principalmente os dois primeiros aspectos. No momento da criação desses órgãos, acreditava-se que ambos seriam instrumentos para aumentar a transparência e possibilitar que juízes e promotores pudessem responder por suas ações e escolhas. Nossa hipótese é que essa expectativa não se realizou. Para testá-la, analisaremos o desenho institucional do CNMP e do CNJ, apontando como a composição e a distribuição de cargos incentivam mais a independência que a accountability e apresentaremos também dados relativos ao comportamento dos Conselhos frente às denúncias disciplinares. A conclusão é que, em virtude da composição majoritária do CNJ e do CNMP por integrantes internos do Judiciário e do MP e da atuação pouco expressiva em relação à punição de juízes e promotores, os órgãos reforçam ainda mais a expressiva independência dessas instituições no Brasil.

Palavras-chave: judiciário; Ministério Público; accountability.

\section{Los Consejos Nacionales de Justicia y el Ministerio Público en Brasil: ¿instrumentos de accountability?}

En las democracias, los consejos, órganos colegiados que operan en el sistema de justicia, tienen diferentes finalidades: fortalecer la independencia del Poder Judicial y del Ministerio Público (MP), incrementar la accountability con relación a jueces y fiscales, y/o mejorar la gestión de la justicia. Este artículo analiza el Consejo Nacional de Justicia (CNJ) y el Consejo Nacional del Ministerio Público (CNMP), considerando principalmente los primeros dos aspectos. Al momento de crear esos órganos, se creía que ambos serían instrumentos para aumentar la transparencia y permitir que jueces y fiscales pudieran responder de sus acciones y opciones. Nuestra hipótesis es que esa expectativa no se ha cumplido. Para probarla, analizaremos el diseño institucional del CNMP y del CNJ, señalando cómo la composición y distribución de cargos fomentan más la independencia que la accountability y también presentaremos datos relacionados con el comportamiento de los consejos ante denuncias disciplinarias. Nuestra conclusión es que, debido al hecho de que el CNJ y el CNMP están compuestos mayoritariamente por miembros internos del Poder Judicial y del MP y al desempeño insignificante con relación al castigo de jueces y fiscales, los órganos refuerzan aún más la significativa independencia de estas instituciones en Brasil.

Palabras clave: Poder Judicial; Ministerio Público; accountability.

\section{The Brazilian Councils of Justice and Public Prosecutor's Office as Instruments of Accountability}

Councils acting in the Justice System in democracies have different purposes: to strengthen the independence of the judiciary and the public prosecutor's office, to increase accountability of judges and prosecutors, or/and to improve justice management. This article analyzes the Brazilian National Council of Justice (CNJ) and the National Council of the Brazilian Public Prosecutor's Office (CNMP), particularly regarding their purpose as instruments of accountability. The study shows that these bodies were created as instruments to increase transparency and compel judges and prosecutors to be held accountable for their actions and choices. The hypothesis tested in this research is that the two councils did not meet this expectation. The CNJ and CNMP were analyzed for their institutional design, discussing how the composition and distribution of positions at the council encourage independence of the judges and prosecutors rather than accountability. In addition, the article offers data on the councils decisions when accusations were presented. Finally, the analysis revealed that CNJ and CNMP are mainly composed of internal members of the Judiciary and the Public Prosecutor's Office, and identified a lack of expressive punishment applied to judges and prosecutors. Therefore, the hypothesis that the councils do not work as instruments of accountability was confirmed. Keywords: judiciary; public prosecutor's office; accountability. 


\section{INTRODUÇÃO}

$\mathrm{Na}$ democracia, atores e agências prestam contas de seus atos a outros atores e agências, podendo ser punidos ou premiados por sua atuação. Para que a accountability seja efetiva, são necessárias autonomia e independência organizacional do fiscalizador em relação ao fiscalizado. Assim, corregedorias, embora cumpram papel relevante na organização interna e possam colaborar com incentivos para a criação de uma política institucional, não funcionam efetivamente como instrumentos de accountability democrática justamente porque o corregedor mantém laços com aqueles que devem ser fiscalizados. São, quando muito, órgãos de controle interno, ou de accountability administrativa, que asseguram uma melhor gestão e o cumprimento diligente de tarefas, mas não implicam necessariamente prestação de contas à sociedade (Poulsen, 2009; Schedler, Diamond, \& Plattner, 1999).

Embora a literatura apresente diversos tipos de accountability (Bovens, Goodin, \& Schillmans, 2014), a mais relevante para a democracia é aquela que se assenta sobre transparência, independência e instrumentos de punição. Quando estes aspectos estão presentes, é racional para aquele que é fiscalizado, baseado na "lei da antecipação das reações" (Brachrach \& Baratz, 1962 como citado em Limongi, 2006, p. 29), buscar desempenhar corretamente suas funções, evitando, assim, punições e sanções.

No governo Lula, em 2004, a criação do Conselho Nacional do Ministério Público (CNMP) e do Conselho Nacional de Justiça (CNJ) - encarregados, entre outras tarefas, de fiscalizar e punir juízes e promotores - parecia sinalizar que os políticos produziriam instrumentos efetivos de accountability democrática em relação ao MP e ao Judiciário. Essa possibilidade, porém, já não era tão alentada à época desta reforma. Ela marcou o debate dos anos 80 e 90 do século passado, em especial o que se travou durante a Assembleia Nacional Constituinte. Contudo a derrota, à época, da tentativa de estabelecer instrumentos de controle externo do Sistema de Justiça, bem como o debate que se lhe seguiu apontaram que o que estava realmente em jogo, na reforma do governo Lula, era a instituição de instrumentos de controle interno (Fragale, 2013; Ribeiro \& Arguelhes, 2015; Ribeiro \& Paula, 2016). O insulamento dessas burocracias, em especial em relação ao MP, é bastante elevado e algo incomum em perspectiva comparada, o que não mudou com essas reformas.

Neste artigo buscamos avaliar se estes Conselhos atenderam à expectativa inicial de se tornarem agências de accountability - ainda que exclusivamente interna - em relação aos juízes e promotores brasileiros. Para tanto, observaremos ambos por meio de suas autonomias e composições e de suas efetivas capacidades de punir aqueles que não observem suas obrigações.

As perguntas que buscaremos responder são: os Conselhos atuam como instrumentos de accountability, levando MP e Judiciário a "prestarem contas" sobre sua atuação? Decorrente desta: estes Conselhos servem como mecanismos para controlar a ampla autonomia de juízes e promotores?

Para respondê-las observaremos dois aspectos. O primeiro diz respeito a uma análise do desenho institucional do CNMP e do CNJ que aponta que a composição e a distribuição de cargos incentivam mais a independência que a accountability. O segundo aspecto refere-se à análise de dados relativos ao comportamento dos Conselhos frente às denúncias disciplinares. O objetivo aqui é verificar o quão efetivos são os órgãos como instrumento de accountability, mesmo em relação àquele que interessa menos do ponto de vista da democracia, ou seja, uma accountability exercida pelos pares. Trata-se de um esforço de compreender os dois principais órgãos de controle do Sistema de Justiça do Brasil, não apenas do ponto de vista da sua composição, mas, sobretudo, de sua atuação e de alguns resultados 
alcançados. Demonstraremos que o CNMP e o CNJ, diferentemente do que se esperava, são órgãos que reforçam ainda mais o insulamento dos promotores e juízes brasileiros, mantendo-os distantes da accountability.

\section{CONSELHOS DE SISTEMAS DE JUSTIÇA}

Diferentes democracias - tais como a francesa, a espanhola, a portuguesa, a italiana, a argentina e a brasileira, entre outras - possuem em sua estrutura uma instituição estatal organizada para tomar decisões de forma colegiada, responsável por regular o Poder Judiciário. Em diferentes sistemas políticos, os Conselhos são incumbidos de distintas atribuições: reforçar a independência das instituições judiciais, incrementar a accountability em relação a juízes e promotores ou aprimorar a gestão da Justiça (Finkel, 2008; Hammergren, 2002; Pessanha, 2013; Pozas-Loyo \& Ríos-Figueroa, 2010, 2010a). Garoupa e Ginsburg (2008) estimam que cerca de 60\% dos países contam com órgãos desse tipo e que eles se ocupam de, ao menos, uma das seguintes tarefas relativas às instituições judiciais: i) housekeeping, ou seja, questões relativas a orçamento, recursos materiais etc.; ii) indicação de juízes; e iii) avaliação de performance (promoção, disciplina, remoções, salários etc.).

Como o Judiciário geralmente é o poder menos accountable, supôs-se que no Brasil a adoção de um Conselho seria uma forma de diminuir o déficit democrático em relação aos juízes. Durante os anos 1980 e 1990 e, em especial, durante a Assembleia Nacional Constituinte, a discussão acerca do Conselho estava voltada para a instituição de um instrumento de controle externo do Poder Judiciário (Fragale, 2013; Ribeiro \& Arguelhes, 2015; Ribeiro \& Paula, 2016). Ou seja, ao se criar uma instituição relativamente apartada do Poder Judiciário para acompanhar e/ou regular as atividades e a carreira de juízes, formada por um certo número de integrantes externos ou oriundos de diferentes instâncias da Justiça, estar-se-ia gestando uma estrutura para aumentar a accountability e diminuir a independência ${ }^{1}$ dos magistrados.

Embora a questão da accountability das instituições judiciais tenha predominado no debate brasileiro, noutros países latino-americanos foi a questão da independência que predominou, o que se refletiu nas reformas judiciais adotadas por estes (Finkel, 2008), até mesmo no que concerne a seus Conselhos, voltados antes ao reforço do Judiciário que ao seu controle (Hammergren, 2002; Pozas-Loyo \& Ríos-Figueroa, 2010a).

Respondendo à expectativa de que Conselhos aumentariam a accountability, restringindo a autonomia dos juízes, criou-se no Brasil o CNJ. Previsto por meio da Emenda Constitucional n. 45 (2004), o Conselho gerou a crença de que se estaria “[...] induzindo uma dimensão específica de controle social cujas possibilidades contrastavam com o anterior modelo de um poder judiciário fragmentado, pulverizado [...]” (Fragale, 2013, p. 2). Segundo o debate na época, “[...] exatamente o controle externo [...] se constituiu na ratio essendi da criação de ambos os Conselhos"2 (Streck, Sarlet, \& Clève, 2005, p. 2), o que gerou desconfiança dos membros do Sistema de Justiça, a ponto de a Associação dos Magistrados Brasileiros (AMB) questionar a instituição do órgão com uma Ação Direta de Inconstitucionalidade (ADI). O questionamento baseava-se na

\footnotetext{
${ }^{1}$ Assim como Dahl (1982), usaremos “independência" e "autonomia” como sinônimos do mesmo fenômeno político que distancia atores estatais da accountability ou dificulta que eles sejam accountable.

${ }^{2}$ Os autores referem-se também ao CNMP.
} 
[...] formação heterogênea no Poder Judiciário para exercer seu controle externo, com membros de outros poderes, desrespeitando (a) tanto o princípio da separação e da independência dos poderes (b) como o pacto federativo, além de inconstitucionalidade formal de parte de sua competência (Pessanha, 2013, p. 509).

A maioria dos ministros do Supremo Tribunal Federal (STF) considerou que a criação do CNJ não iria contra a independência do Judiciário garantida pela Constituição. $\mathrm{O}$ relator, o ministro Cezar Peluso, afirmou que "[...] o Conselho representava, tão somente, uma mudança de arquitetura institucional, cuja nova configuração proporciona uma 'ligeira abertura' do Judiciário à sociedade" (Fragale, 2013, p. 2, grifo nosso). Também Nunes (2010, p. 318) aponta que a criação do Conselho, voltado a uma supervisão administrativa do Judiciário, é incapaz de ameaçar a independência decisória dos juízes. $\mathrm{Na}$ verdade, Nunes aponta para um efeito inverso: um Judiciário mais independente de pressões variadas, sobretudo em seus órgãos de cúpula, seria capaz de reforçar o seu papel de governança, assegurando decisões mais uniformes ao longo de todas as instâncias do sistema judicial. Por conta disso, pode-se mostrar de interesse dos chefes do Executivo nacional promover reformas que reforcem a independência judicial, bem como o poder das instâncias centrais (Nunes, 2010, pp. 313-315).

Em linha com o argumento de Nunes, essa decisão do STF indica que nem sempre a criação de Conselhos de magistrados tem como objetivo principal o aumento da accountability. Muitos são criados como instrumento para incrementar o insulamento dos magistrados, buscando afastar a influência da política partidária do Poder Judiciário. Diante de diversas experiências nas democracias, observa-se que a "[...] accountability externa emergiu como um segundo objetivo dos conselhos" (Garoupa \& Ginsburg, 2008, p. 110) e não como seu principal foco. Em outras palavras, Conselhos, muitas vezes, servem mais à independência do que à accountability. A criação desses órgãos demonstra, na verdade, que existe um trade off entre autonomia e accountability. Ao se aumentar um, diminui-se o outro.

[...] Embora instituições adequadas possam aumentar a independência judicial e minimizar os problemas de um Judiciário politizado, o aumento dos poderes e da independência de que gozam os juízes cria o problema oposto de uma excessiva judicialização das políticas públicas (Garoupa \& Ginsburg, 2008, p. 117).

A adoção de Conselhos que reforçam a independência e não a accountability vai ao encontro da prescrição normativa de que seriam necessárias altas doses de autonomia do Poder Judiciário frente aos outros atores (Kerche, 2018). Afinal, é um "consenso normativo" (Melton \& Ginburg, 2014, p. 187), um “estereótipo normativo" (Maravall, 2003, p. 264) ou um "conceito quasi-religioso" (Taylor, 2017, p. 5) que independência é necessária e essencial para que os juízes resolvam disputas (Shapiro, 2013). Há quase uma unanimidade na literatura sobre o fato de que "[...] Judiciários independentes estão mais bem situados que suas menos independentes contrapartes para fazer valer [enforce] direitos constitucionais contrários às maiorias populares e, dessa forma, corrigir injustiças detectadas" (Clark, 2011, p. 264). Mesmo que autonomia não seja um "valor supremo" - já que consistência, precisão, previsibilidade e rapidez das decisões também são importantes -, é inegável que se trata de "[...] um importante componente em muitas definições de qualidade da Justiça” (Melton \& Ginburg, 2014, p. 190). 
Por outro lado, um Judiciário autônomo, moderado e apartidário pode ser amigável ao governo do dia. Nos termos de Nunes (2010, p. 315):

[...] um judiciário amigável é aquele formado por juízes suficientemente moderados em suas preferências e respeitosos em suas atitudes relativas aos outros ramos do governo [...] Em sistemas multipartidários como o do Brasil, os mandatários podem garantir um judiciário respeitoso nomeando juízes que subscrevam a ideologia legal positivista, que vê o papel judicial como um instrumento de aplicação da lei e não de criação dela.

Assim, se um conselho da magistratura puder, por meio da supervisão administrativa do Judiciário, assegurar maior disciplina interna e independência partidária, pode garantir que as cortes não tentem substituir os legisladores e, consequentemente, o governo. Neste caso, conselhos (como é o caso do brasileiro), formados predominantemente por juízes, são capazes de fazer isso sem ameaçar a independência decisória da magistratura (Nunes, p. 318).

A composição de um Conselho é um indicativo razoável das reais intenções dos legisladores. Pelo número de integrantes externos e internos do Poder Judiciário no colegiado, é possível identificar se o órgão pende mais para a independência ou para a accountability. "Um pressuposto geral na literatura é que uma maioria do Judiciário no conselho assegurará independência” (Melton \& Ginburg, 2014, p. 120). Quando a maioria de seus membros deve ser escolhida necessariamente entre os próprios juízes, menor o espaço para a accountability.

No caso do CNJ, formado por uma maioria de juízes, e "[...] previsto como um órgão integrante do próprio Poder Judiciário" (Lima, 2017, p.13), interpretações conseguem entrever, no máximo, “accountability interno" (Tomio \& Robl, 2013, p. 29). Vale notar, também, que num primeiro momento a redação dada pela Emenda Constitucional n. 45 (2004) previa o seguinte: “[...] os membros do Conselho serão nomeados pelo Presidente da República, depois de aprovada a escolha pela maioria absoluta do Senado Federal" (Art. 103-B $\$ 2^{\circ}$ ), porém, uma nova redação, propiciada pela Emenda Constitucional n. 61 (2009), determinou que "[...] os demais membros do Conselho serão nomeados pelo Presidente da República, depois de aprovada a escolha pela maioria absoluta do Senado Federal". Ou seja, diminuiu-se ainda mais a influência externa na composição do CNJ, restringindo-a à sacramentação dos integrantes que não provêm dos órgãos de cúpula do Judiciário (STF e STJ). ${ }^{3}$

Essa opção de assegurar mais independência ou mais accountability varia entre os Conselhos e é definida, geralmente, no momento de sua criação. A França, por exemplo, que tem como tradição fortes laços entre Poder Judiciário e Executivo (Terquem, 1998), criou um Conselho com uma composição favorável à accountability, justamente para aumentar a autonomia dos juízes, contrabalançando a dependência do governo. Também na busca por um maior equilíbrio, a Espanha, com um Judiciário mais independente, tem um Conselho composto, em sua maioria, por representantes do parlamento (Pessanha, 2014). Por outro lado, na Itália, como consequência do trauma do período fascista, a Constituição de 1948 insulou juízes e promotores das ingerências político-partidárias, o que se reflete também na composição do Conselho, formado exclusivamente por magistrados, sendo a independência a característica primordial (Guarnieri, 2015; Sberna \& Vannucci, 2013).

${ }^{3}$ Agradecemos a um dos pareceristas anônimos por nos chamar a atenção para este ponto. 
Mudanças podem ocorrer com o tempo, levando um Conselho originalmente organizado para reforçar a independência a um modelo que privilegie a accountability. $\mathrm{Na}$ Argentina, por meio de uma reforma promovida pelo governo Cristina Kirchner em 2006, a composição do Conselho da Magistratura foi reformulada visando reforçar a presença de atores externos ao Judiciário, ao mesmo tempo que o número total de conselheiros diminuiu, em uma clara tentativa de restringir a autonomia dos juízes. Dessa forma, "[...] aumentou a influência do poder político representado pela maioria parlamentar e pelo poder executivo, além de excluir o presidente da Suprema Corte de Justicia de La Nación da presidência do Consejo de La Magistratura [...], como constava no desenho original” (Pessanha, 2014, p. 9).

Mesmo havendo significativas diferenças em relação ao papel de juízes e promotores, discussão semelhante àquela apresentada até aqui pode ser feita em relação aos Conselhos de Ministérios Públicos ${ }^{4}$. De tal forma isso se confirma, que alguns Conselhos se encarregam dessas duas funções da Justiça, como é o caso do órgão italiano e do francês. Contudo, se há aspectos que os unem, há diferenças que merecem destaque.

Promotores, diversamente dos juízes, na grande maioria dos casos são subordinados ao Ministério da Justiça de seus países, em um modelo "burocrático" (Kerche, 2018). Existem também os selecionados diretamente pelos eleitores, como os promotores locais nos Estados Unidos. Ou seja, se no Judiciário a regra é a independência dos outros Poderes e, consequentemente, da política partidária, no caso do MP o mais comum são promotores subordinados ao governo (que é accountable perante os eleitores), ou os próprios promotores accountable perante os eleitores. Nesses casos, os integrantes do MP são os gatekeepers (Aaken, Feld, \& Voigt, 2010) que selecionam e priorizam, baseados nas orientações emanadas pelo governo, o que será julgado pelo Judiciário, que normalmente é inerte e só age quando provocado. Isso funciona como uma espécie de regulação do Judiciário pela política. Esse papel de selecionar e priorizar é típico da atividade executiva (Shapiro, 2013).

Assim, geralmente, os promotores implementam a política de segurança pública decidida pelos políticos, accountable perante os eleitores, ou possuem discricionariedade para escolher suas prioridades, mas prestam contas diretamente aos cidadãos por meio de eleições regulares. A relação entre governo e promotores no sistema burocrático, assim como entre eleitores e promotores no processo eleitoral, são marcadas pelas dificuldades inerentes às relações entre principal e agent, como a assimetria de informações, por exemplo. Em regra geral, portanto, o MP é uma instituição do Executivo, embora sua atuação se dê em torno do Judiciário.

Existe também o modelo de MP autônomo. Ao menos dois países adotam um sistema em que os promotores são bastante insulados: Brasil e Itália. Os respectivos Conselhos reforçam a independência dos promotores em relação aos governos e cidadãos e não a accountability, justamente por serem formados por maiorias internas ao MP. A instituição italiana, com seu Conselho composto exclusivamente por magistrados, e a brasileira, na qual dos quatorze conselheiros, apenas dois são indicados pelo Legislativo, são exemplos de Conselhos que fortalecem os Ministérios Públicos que já são autônomos de facto e de jure.

Em suma: Conselhos, embora tenham como ponto comum a existência de um órgão colegiado para acompanhar as atividades de juízes e promotores, servem para diferentes finalidades. Diferentemente de um certo "senso comum", alguns reforçam a autonomia do Poder Judiciário e do MP, outros são

\footnotetext{
${ }^{4}$ Chamaremos de Ministério Público (MP) todas as agências encarregadas da ação penal, independentemente das denominações que possam receber em outros países.
} 
tentativas de produzir accountability política de juízes e promotores. A chave para entender para qual lado pende essa balança é observar a composição desses órgãos.

\section{3. $O$ CONSELHO NACIONAL DO MP}

O MP, desde a Constituição de 1988, foi desligado do Poder Executivo e ganhou altas doses de autonomia, mantendo algumas obrigações e ampliando significativamente outras. Essa autonomia é bastante incomum, mesmo em perspectiva comparada.

Como apontam Arantes e Moreira (2019, p. 103), o MP (assim como a Polícia Federal e as Defensorias Públicas) tem feito uma "política para si", de forma análoga a grupos de interesse na sociedade, comportando-se "[...] como ativistas em defesa de seus próprios projetos de afirmação institucional, direcionando-se para a sociedade em busca de apoio e pressionando os demais atores políticos com vistas a esse fim", conformando o que denominam "pluralismo estatal". Ou seja, atores formados no interior do próprio Estado, em especial os de carreira jurídica, articulando-se com setores da sociedade e pressionando os demais atores políticos em defesa de seus interesses, como se estes fizessem parte das demandas gerais da sociedade.

Durante os governos de Lula (2003-2010) e Dilma Rousseff (2011-2016), o MP tornou-se ainda mais autônomo e discricionário relativamente ao que fora determinado em 1988. Inovações institucionais como a lei que permitiu que promotores conduzissem acordos de delação premiada (Lei 12.850, 2013), a delegação informal para que uma parcela dos próprios procuradores escolhesse o procurador-geral da República, a parceria com a, de facto, autônoma Polícia Federal, o direito de conduzir investigações de matérias penais etc. afastaram ainda mais os promotores da accountability e permitiram que eles tomassem decisões baseados em critérios nem sempre claros. Durante os governos petistas, ora por iniciativa do Executivo, ora pelos outros Poderes, criou-se uma "novíssima" e singular agência responsável pela ação penal (Kerche \& Marona, 2018).

No que seria uma aparente exceção entre as inovações institucionais no sentido de mais autonomia e mais discricionariedade, ainda em 2004, o governo patrocinou e aprovou a criação do CNMP. A expectativa de alguns e o temor de outros era de que esse órgão funcionasse como uma instituição limitadora da autonomia dos promotores (Cardoso, 2004). Contudo, como mostraremos a seguir, o resultado foi bem diferente disso. Uma vez mais tiveram sucesso os membros do MP no reforço de sua independência. Ou, nos termos de Arantes e Moreira (2019, p. 122), "[...] tal como o Conselho Nacional de Justiça, o CNMP se converteu em órgão de administração da própria corporação, de elaboração de políticas e metas para seus membros, antes que um órgão de efetivo controle externo”.

\subsection{0 desenho institucional do CNMP}

O CNMP é composto pelo procurador-geral da República e por mais treze membros, sendo os nomes indicados pelo presidente da República e aprovados pelo Senado para um mandato de dois anos, permitida uma recondução. A perda de mandato somente se dá quando o Senado condena o conselheiro por crime de responsabilidade ou por sentença judicial transitada em julgado para infrações penais comuns. Em tese, essa participação do Executivo e do Legislativo na indicação e na destituição poderia servir como um incentivo para que os conselheiros observassem os desejos dos políticos. Na prática, entretanto, não há indícios de que o papel da Presidência e do Senado seja mais do que simplesmente o de confirmar os nomes sugeridos pelos órgãos do Sistema de Justiça. 
Os integrantes são distribuídos da seguinte forma (Enciclopédia Jurídica da PUC-SP, 2017):

- Quatro integrantes do MP da União, assegurada a representação de cada uma das carreiras (MP Federal, MP do Trabalho; MP Militar; MP do Distrito Federal e Territórios), que apresenta uma lista tríplice;

- Trêsmembros deMPdos estados. Listastríplicessão apresentadaspara os respectivos procuradores-gerais de Justiça. Em reunião do Conselho Nacional dos procuradores-gerais de Justiça (CNPG), os chefes dos MPs decidem os indicados (CNMP, 2017);

- Um juiz indicado pelo STF e outro, pelo STJ. O Supremo abre um edital para receber candidaturas dos interessados (STF, 2017);

- Dois advogados indicados pela Ordem dos Advogados do Brasil (OAB) por meio de votação no Conselho Pleno (Consultor Jurídico, 2017);

- Dois cidadãos com "notório saber jurídico", um indicado pelo Senado e outro, pela Câmara.

A composição do Conselho, em que todos os conselheiros têm formação em Direito, é formada em sua maioria por representantes do próprio MP (oito oriundos deste e seis externos), por indicações de instituições estatais que não passam por processo eleitoral (dez oriundos e quatro externos), por representantes de instituições não diretamente accountable frente aos cidadãos (doze oriundos e dois externos) e apenas dois escolhidos por instituições baseadas no voto dos eleitores ${ }^{5}$. Isso é um indicativo expressivo de que o CNMP não seria um órgão primordialmente de accountability externa do MP como se imaginava em um primeiro momento.

Mesmo as indicações da Câmara e do Senado concentram-se, majoritariamente, em representantes oriundos de assessorias dos Poderes Legislativo e Executivo. Até os dias atuais, apenas dois conselheiros indicados pelo Legislativo não tiveram passagem por órgãos da administração pública. Ter vínculo com os políticos não desqualifica nenhum conselheiro, obviamente, mas pode sugerir que a seleção baseia-se em critérios distintos da ideia de uma ampla representação da sociedade.

\section{QUADRO 1 CONSELHEIROS EXTERNOS DO CNMP}

\begin{tabular}{lll} 
Nome & \multicolumn{1}{c}{ Período } & \multicolumn{1}{c}{ Origem } \\
\hline Alberto Machado Meleiros & $2005-2007$ e 2007-2009 & Advogado-geral do Senado \\
Francisco de Albuquerque & $2005-2007$ e 2007-2009 & Advogado \\
Bruno Dantas & $2009-2011$ & Consultor legislativo \\
Luiz Moreira Gomes Jr. & $2010-2012$ e 2013-2015 & Professor Universitário de Direito \\
Fabiano Silveira* & $2011-2013$ & Consultor legislativo \\
Gustavo do Vale Rocha & $2015-2017$ e 2017-2019 & Subchefe de assuntos jurídicos da Casa Civil \\
Luiz Fernando Bandeira de Mello Filho & $2017-2019$ & Secretário-Geral da Mesa do Senado
\end{tabular}

${ }^{\star}$ Foi também conselheiro do CNJ e ministro da Transparência no governo Temer. Fonte: CNMP (2019).

\footnotetext{
${ }^{5}$ Houve uma tentativa de ocupar a vaga de conselheiro externo com um membro oriundo do próprio MP. Esta tentativa foi barrada por decisão de ministro do STF. Recuperado de https://www1.folha.uol.com.br/fsp/brasil/fc0408200715.htm
} 
São duas as grandes atribuições do CNMP: o controle "da atuação administrativa e financeira" do MP e "dos deveres funcionais de seus membros" (Regimento Interno do CNMP, art. 2). Embora "controle" seja o aspecto comum, a primeira reforça a autonomia, enquanto a segunda, em teoria, a accountability.

Pelo lado da autonomia, cabe ao CNMP “[...] zelar pela autonomia funcional e administrativa [...], podendo expedir atos regulamentares no âmbito de sua competência, ou recomendar providências" (Regimento Interno do CNMP, art. $\left.2^{\circ}, \mathrm{I}\right)^{6}$. Isso abre espaço à criação de regras para o MP sem passar pelo Legislativo. São diversos os exemplos em que o CNMP buscou reforçar ainda mais a autonomia e discricionariedade dos promotores, legislando de forma controversa no que concerne à sua constitucionalidade. Selecionamos três exemplos que ilustram esse ponto.

O primeiro refere-se à criação do Procedimento de Investigação Criminal (PIC) (Resolução n. 13, 2006). Por meio dessa decisão, o CNMP previu um

[...] instrumento de natureza administrativa e inquisitorial, instaurado e presidido pelo membro do Ministério Público com atribuição criminal [...] [tendo] como finalidade apurar a ocorrência de infrações penais de natureza pública, servindo como preparação e embasamento para o juízo de propositura, ou não, da respectiva ação penal (Cap. I, art. $1^{\circ}$ ).

O problema é que o texto constitucional previa que procedimentos investigatórios criminais fossem atribuição da polícia, rechaçando a possibilidade, proposta pelo lobby do MP durante o processo constituinte, de compartilhar o inquérito ou que esse fosse presidido pelo promotor. A ideia seria a criação de uma divisão de tarefas que gerasse uma espécie de "piloto automático" (Sutherland, 1993) no Sistema de Justiça, em que instituições se autolimitariam em um modelo "competitivo" (Arantes, 2011): a polícia investiga, o MP acusa e o juiz decide (Kerche, 2009). O CNMP, portanto, sem a participação do Legislativo, editou um procedimento passível de questionamento constitucional - o que acabou ocorrendo - e que somente foi pacificado em 2015 após uma decisão do STF, que reconheceu a competência investigatória do MP por 7 votos a 4 (STF, 2015).

O segundo exemplo no sentido de aumentar a discricionariedade e autonomia do MP, mesmo que de forma diversa à decisão dos políticos, ocorreu em 2017. Os conselheiros decidiram garantir discricionariedade "[...] para que o MP desista de persecução penal em troca da confissão de suspeitos, em crimes sem violência ou grave ameaça [...] desde que o dano seja inferior a 20 salários mínimos (R\$ 19,5 mil)" (Consultor Jurídico [Conjur], 2017). A polêmica em torno dessa decisão deve-se ao fato de o Brasil não adotar o "princípio da oportunidade" em relação à ação penal, mas o da "legalidade". "Sob esse princípio, é obrigatória a instauração de processo para todos os delitos sobre os quais existam evidência de culpa do acusado, e o critério de interesse público é irrelevante na tomada de decisão do promotor" (Fionda, 1995, p. 9). Diferentemente dos modelos de MP burocrático e eleitoral, no qual promotores detêm discricionariedade justamente por

\footnotetext{
${ }^{6}$ O CNMP, por exemplo, autoriza o orçamento proposto pelo Ministério Público Federal que será apresentado ao Poder Legislativo. Recuperado de http://agenciabrasil.ebc.com.br/justica/noticia/2018-08/mpf-aprova-reajuste-de-1638-em-salario-de-procuradores-darepublica
} 
terem de prestar contas de suas escolhas, o modelo independente brasileiro é previsto para que os promotores levem todos os casos encaminhados pela polícia ao Judiciário. Além de diminuir a discricionariedade de um ator não accountable, esse procedimento reforçaria a divisão de tarefas, uma vez que policial, promotor e juiz se autocontrolariam. Com a decisão de flexibilizar o princípio da legalidade, o CNMP assegurou discricionariedade aos promotores sem que isso tenha resultado de uma decisão legislativa.

Outro exemplo são os casos de autorização para que promotores exerçam cargos em outros Poderes. Segundo a Constituição (art.128, II, c), é vedado aos membros “[...] exercer, ainda que em disponibilidade, qualquer outra função pública, salvo uma de magistério", ponto reforçado em 2007, quando o STF declarou ser contrário a promotores assumirem ministérios, secretarias ou chefias de missão diplomática. Integrantes do MP somente poderiam se afastar para ocupar cargos dentro da própria instituição. A questão ganhou destaque quando, no final do segundo governo de Dilma Rousseff, em março de 2016, o CNMP permitiu que um membro do MP da Bahia, Wellington César Lima e Silva, assumisse o Ministério da Justiça, à semelhança de outros cinco casos aprovados pelo Conselho (Conjur, 2016). Frente à repercussão negativa, diferentemente dos outros exemplos, o STF anulou a posse (Brígido, 2016), agravando a crise que precedeu o impeachment da presidente Dilma Rousseff.

Pelo lado da accountability, o CNMP pode "receber e conhecer das reclamações" (RI, art.2, III) de qualquer cidadão. Limitados pela especificidade de cada Lei Orgânica Estadual (Lima, 2017), os conselheiros podem determinar a remoção, disponibilidade ou aposentadoria com vencimentos, bem como "outras sanções administrativas" (RI, art, $2^{\circ}$, III) ${ }^{7}$. Assim, o Conselho se transforma em mais um canal, além das corregedorias, por meio do qual cidadãos podem denunciar e buscar a punição de promotores que se desviem de suas funções. Discutiremos adiante a respeito da efetividade, ou não, do Conselho no uso dos seus instrumentos institucionais.

Duas instâncias do CNMP são fundamentais para receber denúncias e decidir a seu respeito: a Corregedoria Nacional e o Plenário. A Corregedoria pode receber a "reclamação disciplinar", arquivá-la, instaurar sindicância, encaminhar para o MP local ou instaurar processo administrativo disciplinar (PAD) que será avaliado pelo Plenário. Ou seja, o corregedor é um gatekeeper, que pode filtrar e decidir de forma monocrática o que será decidido pelo CNMP. Os conselheiros, por sua vez, recebem as denúncias por meio da Corregedoria ou são provocados diretamente por uma denúncia externa. Isso pode ser feito por meio de um PAD, um pedido de "avocação", uma "revisão de processo disciplinar" ou uma "representação por inércia ou excesso de prazo" (Regimento Interno do CNMP, 2020). Em termos gerais, a decisão pode ser arquivamento, condenação ou absolvição. Abaixo, o Fluxograma 1 representando essas alternativas.

\footnotetext{
7 "Essas outras sanções administrativas são aquelas previstas nas Leis Orgânicas Estaduais e na Lei Complementar n. 75/1993 e são as seguintes: multa (prevista nos Ministérios Públicos do Piauí, Rio Grande do Sul e Tocantins), admoestação (...Piauí e Roraima) advertência, censura, suspensão, exoneração (... Minas Gerais), demissão, cassação de aposentadoria e disponibilidade, perda de cargo, cassação de aposentadoria e cassação da promoção ou remoção (...Pará)" (Lima, 2017, p. 19).
} 


\section{FLUXOGRAMA 10 CAMINHO DAS DENÚNCIAS DISCIPLINARES NO CNMP}

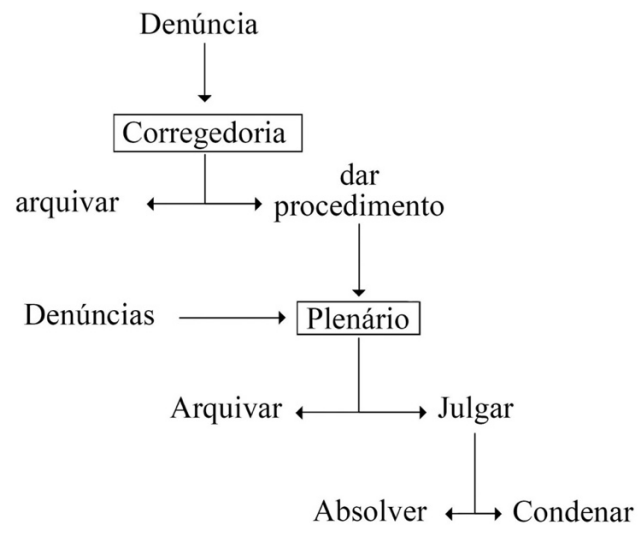

Fonte: Elaborado pelos autores com base em CNMP (2019).

O corregedor nacional, portanto, exerce papel chave para a accountability no CNMP ${ }^{8}$. Ele é um canal mais direto e simplificado do que o Plenário para "[...] receber reclamações e denúncias, de qualquer interessado, relativas aos membros do Ministério Público" (Regimento Interno do CNMP, art.18, I), exercer o papel de inspeção e correição dos diferentes ramos do MP e “[...] instaurar de ofício [...] processo administrativo disciplinar" (Regimento Interno do CNMP, art. 18, VI). Ademais, o corregedor pode avocar, de ofício, "[...] procedimentos de natureza investigativa ou inquisitiva, preparatórios de processo administrativo disciplinar, em trâmite no Ministério Público” (Regimento Interno do CNMP, art. 18, XVII), e também "[...] processo administrativo disciplinar em trâmite no Ministério Público" (Regimento Interno do CNMP, art.18, XVIII), ambos ad referendum do Plenário.

O corregedor é eleito pelo Plenário para um mandato de dois anos, sem possibilidade de recondução. A Corregedoria é privativa dos conselheiros que são membros de carreira do MP, de modo que a posição chave para a accountability, com altas doses de discricionariedade, somente é exercida por um integrante da instituição fiscalizada. Mais uma vez, há um indicativo de que o CNMP é mais um instrumento de reforço da independência e menos de incremento da accountability.

O Quadro 2 apresenta os nomes, o período e a origem dos corregedores nacionais. Vale destacar que todos os ramos do MP da União, com exceção do Federal, assim como representantes dos estaduais, foram contemplados. Uma possível especulação é que, uma vez que o presidente do CNMP é o procurador-geral da República (PGR), e este vinha sendo escolhido pelos próprios procuradores federais ${ }^{9}$, o cargo de corregedor seria reservado para outros ramos, buscando-se, com isso, algum tipo de equilíbrio interno.

\footnotetext{
${ }^{8}$ Existe também o cargo de ouvidor do CNMP. Eleito entre os conselheiros para um mandato de um ano, podendo ser reconduzido para mais um período, seu papel é de esclarecer aos cidadãos sobre as atividades do Conselho e do MP, bem como o de incrementar a transparência; não possui, no entanto, instrumentos de punição dos promotores.

${ }^{9}$ Embora esta não seja uma regra formalizada, os governos observaram a lista tríplice do MPF desde 2003. Essa prática foi interrompida em 2018 por Jair Bolsonaro, nomeando Augusto Aras, que sequer disputara a eleição para a lista tríplice.
} 
QUADRO 2 LISTA DE NOMES, PERÍODO E ORIGEM DO CORREGEDOR NACIONAL (CNMP)

\begin{tabular}{lll}
\hline Nome & Período & \\
\hline Ivana Auxiliadora Mendonça Santos & $2005-2007$ & Ministério Público do Trabalho \\
Osmar Machado Fernandes & $2007-2009$ & Ministério Público Militar \\
Sandro José Neis & $2009-2011$ & Ministério Público de Santa Catarina \\
Jeferson Luiz Pereira Coelho & $2011-2013$ & Ministério Público do Trabalho \\
Alessandro Tramujai Assad & $2013-2015$ & Ministério Público de Roraima \\
Cláudio Henrique Portela do Rego & $2015-2017$ & Ministério Público do Distrito Federal e Territórios \\
Orlando Rachadel Moreira & $2017-2019$ & Ministério Público de Sergipe
\end{tabular}

Fonte: CNMP (2019).

\subsection{CNMP e os processos disciplinares}

Outro aspecto para a discussão sobre se o CNMP é mais uma agência de accountability ou de reforço da autonomia do MP concerne a seu papel nas denúncias disciplinares. Estas podem tratar do comportamento de um integrante do MP no exercício da função ou de uma falta não atinente à atividade profissional, da não observância dos prazos ou mesmo de uma solicitação para que o CNMP avoque procedimento de corregedoria local. Os dados apresentados pelo CNMP, tanto em relatórios de atividades ou por meio da Lei de Acesso à Informação (LAI), não diferenciam punições de promotores daquelas de funcionários.

Se o CNMP for entendido pelos promotores como verdadeira instância de fiscalização - se não democraticamente, já que exercido internamente, ao menos administrativamente -, isso pode incentivar ou desestimular condutas. Ou seja, se o Conselho for efetivo e percebido como instrumento de accountability administrativo, pode moldar comportamentos e aumentar a previsibilidade de atuação do MP. Se for uma instância ineficaz de acompanhamento e punição de desvios, não afetará as escolhas.

Há um senão. O fato de haver poucas punições pode significar apenas que os promotores se adiantam aos conselheiros, evitando sanções ${ }^{10}$. Mesmo os dados mostrando que a punição a um membro do MP é improvável, a dúvida não é sanada: há pouca punição porque os membros do MP erram pouco, ou porque o CNMP os protege? Embora as punições sejam raras e brandas, os dados sugerem, não comprovam, a baixa efetividade da accountability do CNMP.

De qualquer forma, obter a punição de um promotor por sua atuação é uma corrida de obstáculos, um funil com passagem estreita, embora o número de punições tenha crescido. Entre janeiro de 2010 e fevereiro de 2019, foram mais de 2.834 processos disciplinares que chegaram ao CNMP, o que dá uma média de 83 por mês. Já o Plenário decidiu, entre abril de 2007 e novembro de 2018, 509 processos, gerando 223 punições de diferentes tipos (ver gráficos 1 e 2), uma média mensal de

\footnotetext{
${ }^{10}$ Este argumento é baseado no modelo principal/agent (Calvert, McCubbins, \& Weingast, 1989).
} 
1,75 punição por mês. Mantida a média mensal de processos e punições para o mesmo período, somente $2,1 \%$ dos casos resultam em alguma pena. Entre elas, quase metade (47\%) foi relativamente leve, como censura, advertência ou admoestação verbal. Além disso, nem todas as punições são de promotores ou dizem respeito a atividades típicas do $\mathrm{MP}^{11}$.

\section{GRÁFICO 1 PUNIÇÕES POR TIPO NO CNMP (2007-2018)}

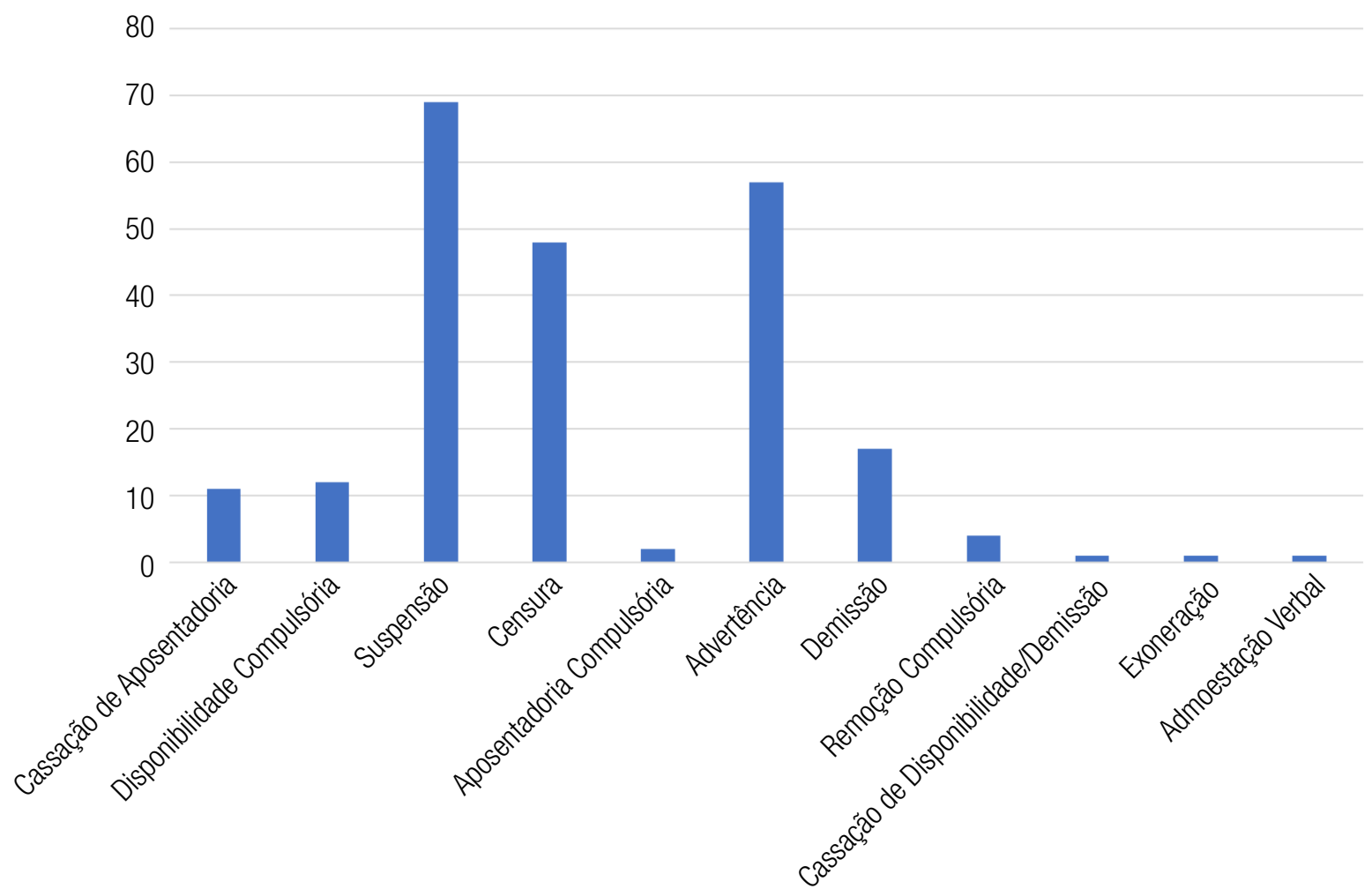

Fonte: CNMP (via LAI) (2019).

Apesar do aumento recente no número de punições, os procedimentos institucionais protegem fortemente os membros do MP. Recursos e prazos são favoráveis ao acusado, atores chave no processo geralmente são colegas de instituição - como o corregedor, o presidente - e há maior probabilidade de que o relator seja um dos conselheiros internos. Além disso, enquanto decisões no CNMP exigem maioria de votos, para questões disciplinares os requisitos são mais elevados: maioria absoluta, independentemente do número de conselheiros presentes à votação.

\footnotetext{
${ }^{11}$ Em 2016, por exemplo, um promotor foi punido por bater na esposa e mantê-la em cárcere privado. Recuperado de https://www1. folha.uol.com.br/poder/2016/04/1757766-cnmp-decide-pela-demissao-de-procurador-acusado-de-agredir-a-mulher.shtml
} 


\section{GRÁFICO 2 PUNIÇÕES POR ANO NO CNMP (2007-2018)}

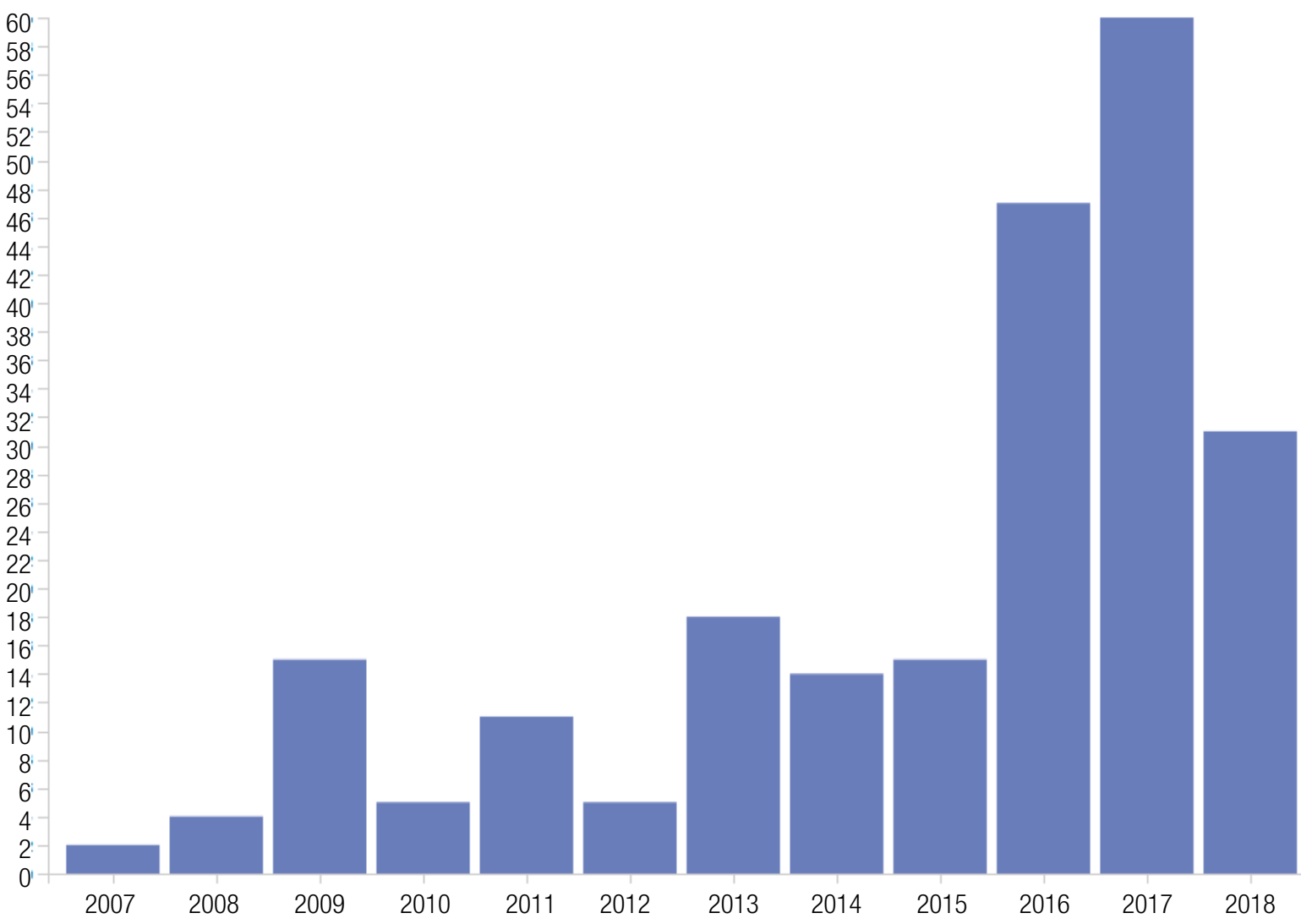

Fonte: CNMP (via LAI) (2019).

\section{0 CONSELHO NACIONAL DE JUSTIÇA}

O Brasil somente criou seu Conselho de Justiça em 2005. Venezuela e Peru criaram os seus ainda na década de 1960 (Carvalho \& Leitão, 2013); a Colômbia contou com um ao final dos anos 1970 e diversos outros países os criaram durante os anos de 1980 e 1990 (Pozas-Loyo \& Ríos-Figueroa, 2010a). A criação tardia não impediu a forte resistência por parte dos integrantes do Judiciário, preocupados com a garantia da independência judicial - talvez até mesmo se deva a esta. A objeção é explicitada em pesquisa realizada antes da Emenda Constitucional n. 45 (2014), a qual apontava que, de 738 juízes, somente $20 \%$ eram favoráveis à participação de membros externos e $47 \%$ eram claramente contrários. Mais revelador ainda: 25,5\% eram contrários à própria criação de um conselho (Sadek, 2001). Estes dados demonstram que juízes viam instrumentos de controle e accountability do Judiciário como indesejáveis. Os que ainda consideravam que o CNJ deveria existir defendiam que fosse composto unicamente por magistrados, sem atores externos. Já a OAB defendia a importância do Conselho (Carvalho \& Leitão, 2013).

No modelo adotado no Brasil, a balança pendeu para o reforço da independência e não para a accountability, não somente pela composição majoritária de membros internos, mas pelo proeminente papel do STF. Cabe ao Supremo indicar membros e presidir o Conselho (por meio do próprio presidente da Corte). Portanto, o STF tem protagonismo na atividade administrativa e disciplinar do CNJ (Carvalho, 2006), pois seu presidente detém poder de agenda (Fragale, 2013; Ribeiro \& Arguelhes, 2015). 


\subsection{Desenho institucional do CNJ}

O CNJ é comporto por quinze membros, com mandato de dois anos e possibilidade de uma recondução. Os membros são nomeados pelo presidente da República, depois de aprovados pelo Senado. A maioria é formada por membros do próprio Judiciário (nove oriundos deste e seis externos), por indicações de instituições estatais que não passam por processo eleitoral (onze oriundos e quatro externos), por instituições não accountable perante os cidadãos (treze oriundos e dois externos) e apenas dois escolhidos exclusivamente por instituições baseadas no voto dos cidadãos.

Dada essa composição, o ministro do STF, Luiz Roberto Barroso, afirmou que não seria possível “[...] referir-se ao Conselho Nacional de Justiça como órgão de controle externo”, pois o Judiciário “[...] detém 3/5 dos seus membros" e, ainda, suas decisões “[...] poderão ser impugnadas judicialmente e a decisão judicial, nesse particular, não caberá ao Conselho, mas a outro órgão do Judiciário [o STF]" (Barroso, 2008 como citado em Pessanha, 2014, p. 14).

\section{QUADRO 3 COMPOSIÇÃO DO CONSELHO NACIONAL DE JUSTIÇA (CNJ)}

\begin{tabular}{|c|c|}
\hline Membros & Quem indica \\
\hline \multicolumn{2}{|l|}{ Tribunais Superiores } \\
\hline 1 ministro do STF* & Presidente do STF \\
\hline 1 ministro do STJ** & STJ \\
\hline 1 ministro do TST & TST \\
\hline \multicolumn{2}{|l|}{ Justiça Estadual } \\
\hline 1 desembargador de Tribunal de Justiça & STF \\
\hline 1 juiz estadual & STF \\
\hline \multicolumn{2}{|l|}{ Justiça Federal } \\
\hline 1 juiz de Tribunal Regional Federal & STJ \\
\hline 1 juiz federal & STJ \\
\hline 1 juiz de Tribunal Regional do Trabalho & TST \\
\hline 1 juiz do trabalho & TST \\
\hline \multicolumn{2}{|l|}{ Ministério Público } \\
\hline 1 membro do Ministério Público da União & Procurador-Geral da República \\
\hline 1 membro de Ministério Público estadual & Procurador-Geral da República; indicações pelos MPEs \\
\hline \multicolumn{2}{|l|}{ Externos ao Judiciário e ao Ministério Público } \\
\hline 2 advogados & Conselho Federal da OAB \\
\hline 2 cidadãos, de notável saber jurídico e reputação ilibada & Um pela Câmara; um pelo Senado Federal \\
\hline
\end{tabular}


Dos conselheiros externos ao Judiciário, indicados pela Câmara e pelo Senado, todos são oriundos do mundo do Direito, como demonstram os dados do Quadro 4. Interessante notar que dos nove conselheiros, dois foram também do CNMP. Ainda, outros dois tiveram passagem pelo Legislativo e um pelo Executivo municipal. Os demais eram advogados e professores de direito (um deles se tornou ministro do STF).

\section{QUADRO 4 CONSELHEIROS EXTERNOS DO CNJ, INDICADOS PELO LEGISLATIVO}

\begin{tabular}{|c|c|c|c|}
\hline Nome & Indicado/a por & Período & Função \\
\hline Alexandre de Moraes & Câmara dos Deputados & $2005-2007$ & Professor Associado de Direito da USP. \\
\hline Joaquim Falcão & Senado Federal & $2005-2007$ & Professor Titular de Direito da FGV Rio. \\
\hline Marcelo Nobre & Câmara dos Deputados & 2007-2009 & $\begin{array}{l}\text { Advogado. Foi Chefe de Gabinete do } \\
\text { vice-prefeito de São Paulo, Hélio Bicudo (gestão } \\
\text { Marta Suplicy). }\end{array}$ \\
\hline Joaquim Falcão & Senado Federal & 2007-2009 & Professor Titular de Direito da FGV Rio. \\
\hline Marcelo Nobre & Câmara dos Deputados & $2009-2011$ & $\begin{array}{l}\text { Advogado. Foi Chefe de Gabinete do } \\
\text { vice-prefeito de São Paulo, Hélio Bicudo (gestão } \\
\text { Marta Suplicy). }\end{array}$ \\
\hline Marcelo Neves & Senado Federal & $2009-2011$ & Professor Titular de Direito da UnB. \\
\hline $\begin{array}{l}\text { Emmanoel Campelo de } \\
\text { Souza Pereira }\end{array}$ & Câmara dos Deputados & 2011-2013 & $\begin{array}{l}\text { Assessor parlamentar da Câmara dos Deputados } \\
\text { 2008-2011. }\end{array}$ \\
\hline Bruno Dantas & Senado Federal & 2011-2013 & $\begin{array}{l}\text { Consultor legislativo. Foi conselheiro do CNMP } \\
\text { (2009-2011). }\end{array}$ \\
\hline $\begin{array}{l}\text { Emmanoel Campelo de } \\
\text { Souza Pereira }\end{array}$ & Câmara dos Deputados & 2013-2015 & $\begin{array}{l}\text { Assessor parlamentar da Câmara dos Deputados } \\
\text { 2008-2011. }\end{array}$ \\
\hline $\begin{array}{l}\text { Fabiano Augusto } \\
\text { Martins Silveira }\end{array}$ & Senado Federal & 2013-2015 & $\begin{array}{l}\text { Consultor Legislativo. Foi conselheiro do CNMP } \\
\text { (2011-2013). }\end{array}$ \\
\hline $\begin{array}{l}\text { Emmanoel Campelo de } \\
\text { Souza Pereira }\end{array}$ & Câmara dos Deputados & 2015-2017 & $\begin{array}{l}\text { Assessor parlamentar da Câmara dos Deputados } \\
\text { 2008-2011. }\end{array}$ \\
\hline $\begin{array}{l}\text { Fabiano Augusto } \\
\text { Martins Silveira }\end{array}$ & Senado Federal & $2015-2017$ & $\begin{array}{l}\text { Consultor Legislativo. Foi conselheiro do CNMP } \\
\text { (2011-2013). }\end{array}$ \\
\hline $\begin{array}{l}\text { Maria Tereza Uille } \\
\text { Gomes }\end{array}$ & Câmara dos Deputados & 2017-2019 & Procuradora de Justiça (desde 2010). \\
\hline $\begin{array}{l}\text { Henrique de Almeida } \\
\text { Ávila }\end{array}$ & Senado Federal & 2017-2019 & $\begin{array}{l}\text { Professor Adjunto de Direito Processual Civil do } \\
\text { Instituto Brasiliense de Direito Público (IDP). }\end{array}$ \\
\hline
\end{tabular}

Fonte: CNJ (2020b). 
Além das resistências iniciais, não foram poucas as críticas também após a criação do Conselho. Numa demonstração de que a iniciativa de uma corregedoria mais ativista pode alterar a dinâmica do órgão de controle, em 2011 a corregedora Eliana Calmon (2009-2012) adotou uma série de medidas administrativas, como "[...] corte de salários acima do teto, proibição de nepotismo, estabelecimento de horários de trabalho nos Tribunais e metas de produtividade com a exposição transparente de dados comparativos dos tribunais estaduais e federais" (Pessanha, 2014, p. 14). Foram várias iniciativas com o objetivo de aumentar a transparência e regulamentar aspectos exigidos em burocracias públicas; não foram, no entanto, bem recebidas pelos magistrados. A crise se agravou quando a corregedora editou a Resolução CNJ-135 (2011), que tratava da punição dos juízes acusados de desvios, de acordo com os regramentos constitucionais que atribuem ao $\mathrm{CNJ}$ o poder de "[...] receber e conhecer das reclamações contra membros ou órgãos do Poder Judiciário (...) sem prejuízo da competência disciplinar e correcional dos tribunais" (Constituição da República Federativa do Brasil, artigo 103B, \# 4', III, grifos nossos)”. Conforme explicou Pessanha (2014, p. 14), “[...] enquanto para alguns a competência concorrente do 'CNJ e dos tribunais' era clara, para outros, principalmente as associações profissionais, tratava-se de uma competência subsidiaria do Conselho". A preferência das associações era pelo julgamento dos pares, por meio do controle interno dos seus próprios tribunais, e não pelo $\mathrm{CNJ}$, em resistência à centralização dos poderes de controle no âmbito do Conselho (Ribeiro \& Arguelhes, 2015).

Questionando essa medida, ação direta de inconstitucionalidade foi impetrada pela AMB (ADI 4638) (STF, 2012). A liminar suspendeu a portaria e a ação foi julgada dois meses depois, mantendo a competência do CNJ por maioria de apenas um voto. Conforme Pessanha (2014), a decisão permitiu à Corregedoria Nacional do CNJ investigar magistrados, mesmo quando seus respectivos tribunais não dessem início ao processo.

Importante salientar, neste caso, que dos seis ministros favoráveis às prerrogativas do CNJ, cinco não eram juízes de carreira; enquanto dos cinco contrários, quatro provinham do Judiciário. Em seu voto, o ministro Gilmar Mendes defendeu a competência do CNJ independentemente das corregedorias dos tribunais: "[...] até as pedras sabem que as corregedorias não funcionam quando se cuida de julgar os próprios pares" (Haidar, 2012). Tal decisão foi crucial para assegurar ao CNJ autonomia e poder para o controle interno das ações e atividades administrativas de membros do Judiciário.

Outra decisão importante, tomada nesta mesma sessão do STF, concernia ao tratamento de problemas disciplinares de juízes discutidos no $\mathrm{CNJ}$ em sessões abertas ou reservadas. A sessão aberta foi aprovada por 9 votos a 2. Contrário a ela, o ministro Luiz Fux questionou: "[...] como pode o magistrado exercer suas funções submetido a um julgamento público?” (Haidar, 2012).

\subsection{CNJ e os processos disciplinares}

Há quatro aspectos importantes do controle de uma instituição como o Judiciário: (1) transparência, (2) custos, (3) conduta de seus membros e (4) efetividade no cumprimento de sua função. Evidentemente esses aspectos estão relacionados, visto que a transparência é um instrumento importante para que se controlem os outros três, assim como a conduta dos membros terá efeito sobre a efetividade da própria instituição como um todo. Porém, cada um desses elementos é relevante em si mesmo. 
No que concerne ao controle disciplinar dos magistrados, entre agosto de 2016 e junho de 2017, a CNJ recebeu 7,6 mil processos (Conjur, 2017b) Não há, contudo, levantamento sobre a efetividade desse controle no que diz respeito à sanção de transgressões cometidas por juízes. Uma prospecção no sítio do CNJ (https://www.cnj.jus.br) mostrou que é possível acessar ali informações relativas ao conteúdo dos processos, ainda que os mecanismos de busca na página não permitam uma organização mais bem estruturada dos dados, por exemplo, ordenando-os por data dos processos, o que dificulta a sua sistematização.

Por meio da Lei de Acesso à Informação (LAI), obtivemos os números dos processos e as penalidades aplicadas pelo CNJ no período entre 2007 e 2018. Os dados são apresentados na tabela abaixo. No entanto, não é possível saber o cargo do servidor penalizado - este dado foi solicitado, mas não fornecido.

\section{GRÁFICO 3 PUNIÇÕES APLICADAS NO CNJ POR TIPO (2006-2018)}

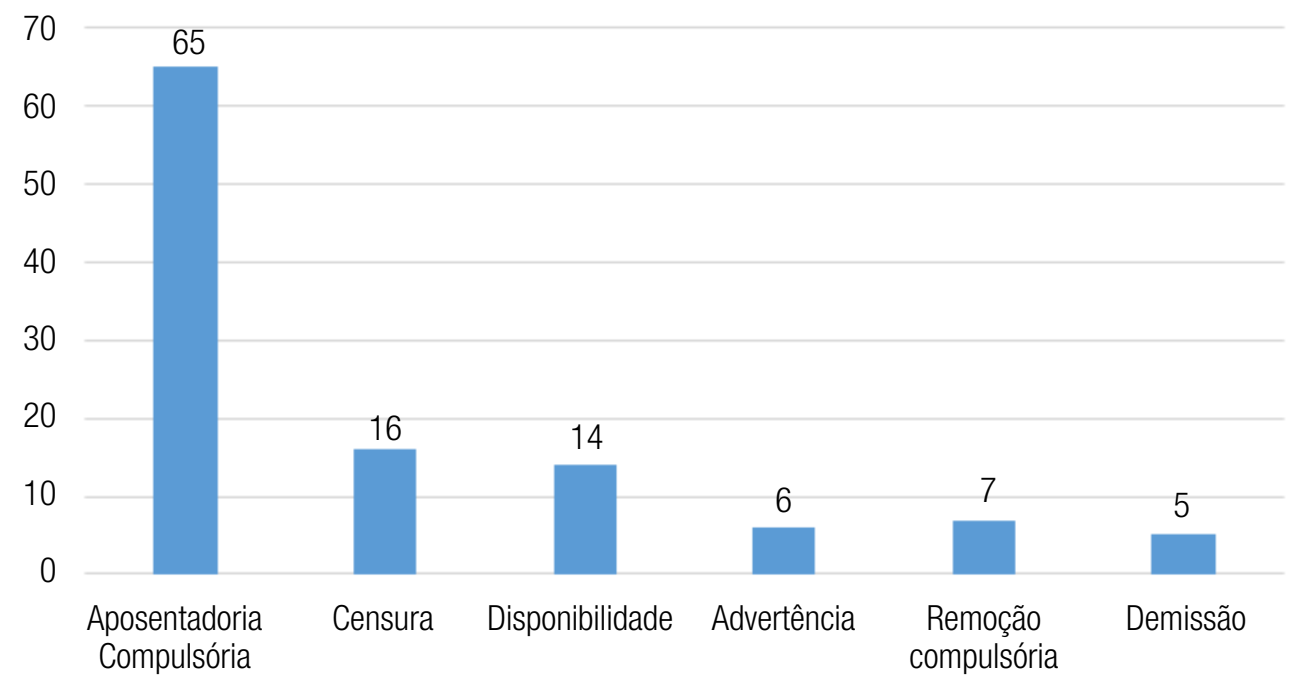

Fonte: $\mathrm{CNJ}$ (via LAI).

Embora a pena mais grave prevista na Lei Orgânica da Magistratura (LOMAN) seja a demissão do juiz, ela requer condições específicas. Para juízes vitalícios, é necessária uma ação penal por crime ou, no caso de medida administrativa, ele deve ter exercido outra função empregatícia, atividade político-partidária ou recebido algum valor em processos sob sua responsabilidade (Lei Complementar 35, de 14 de março de 1979). Também juízes não vitalícios estão sujeitos a demissão por negligência, quebra de decoro ou incapacidade de trabalho (Lei Complementar 35, de 14 de março de 1979). Curiosamente, estas são as mesmas condições para que seja aplicada a pena mais severa possível aos magistrados vitalícios, a aposentadoria compulsória. Por isso mesmo, é essa a punição mais comum no âmbito de um órgão de accountability administrativo como o CNJ.

Ela foi aplicada a 65 magistrados no período entre 2006 e 2018 - contrastando com o que ocorre no CNMP, em que a aposentadoria fica apenas em oitavo lugar entre as punições. De 113 casos com punição (num total de 153 casos no CNJ), apenas cinco resultaram em demissão. Dos casos que não 
resultaram em punição, trinta foram considerados improcedentes, seis foram arquivados, três foram absolvidos e um prescreveu.

Com relação às punições por ano, a gestão de Eliana Calmon (2009-2012) à frente da Corregedoria marca um período de forte atuação do $\mathrm{CNJ}$ em termos de penalidades aplicadas. Foram cinquenta punições, quase $45 \%$ das sanções de todo o termo de treze anos.

\section{GRÁFICO 4 PUNIÇ̃̃ES APLICADAS NO CNJ POR ANO (2006-2018)}

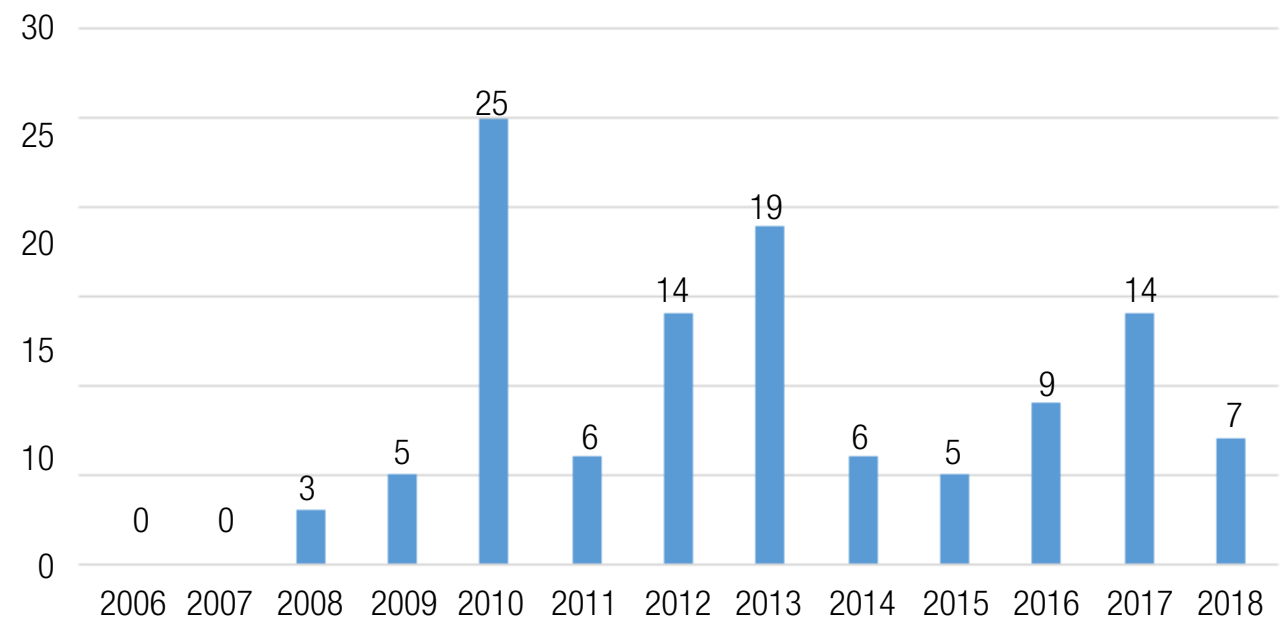

Fonte: CNJ (via LAI).

Interessante notar a distribuição geográfica das penalidades aplicadas pelo CNJ, apresentadas no Quadro 5.

QUADRO 5 PENALIDADES DO CNJ POR TRIBUNAL

\begin{tabular}{l|clc|}
\hline Tribunal & Penalidades & Tribunal & Penalidades \\
STJ & 1 & TJPI & 5 \\
TJAL & 6 & TJPR & 1 \\
TJAM & 6 & TJRJ & 2 \\
TJAP & 1 & TJRN & 4 \\
TJBA & 7 & TJRO & 4 \\
TJCE & 4 & TJRR & 2 \\
TJGO & 2 & TJSC & 1 \\
TJMA & 17 & TJSP & 1 \\
\cline { 1 - 3 } & & & \multicolumn{2}{c}{ Continua }
\end{tabular}




\begin{tabular}{lcllc}
\hline Tribunal & Penalidades & Tribunal & Penalidades \\
TJMG & 5 & TJT0 & 3 \\
TJMMG & 2 & TRF4 & 4 \\
TJMS & 2 & TRF1 & 2 \\
TJMT & 12 & TRF2 & 1 \\
TJPA & 7 & TRT 14 & 3 \\
TJPB & 4 & TRT22 & 1 \\
TJPE & 2 & TRT3 & 1 \\
Total & & & 113 \\
\hline
\end{tabular}

Fonte: CNJ (via LAI).

É interessante observar que entre os TJs, os cinco estados com maior número de punições são responsáveis por metade delas (AL, AM, BA, MA e MT). Todos eles (com exceção da Bahia) são estados periféricos no concerto federativo, destoando de São Paulo, com o maior dos TJs, que teve uma única punição ${ }^{12}$.

Outra questão que merece destaque diz respeito ao tempo de resposta e à possibilidade de enforcement das decisões do $\mathrm{CNJ}$ na punição de excessos cometidos pelos membros do Judiciário. A demora no julgamento dos casos de abuso de poder por membros do Judiciário ou mesmo penas que são consideradas punições por tais membros, mas não pelo restante da sociedade, são aspectos que enfraquecem os mecanismos de controle social, cuja institucionalização no Brasil ainda é incipiente. Exemplo claro disso foi a decisão do CNJ de punir a juíza Clarice Maria de Andrade, que manteve uma jovem de 15 anos presa por 26 dias numa cela com trinta detentos homens, na delegacia de Abaetetuba, no Pará, em 2007. O caso foi julgado pelo CNJ em 2010, sendo aplicada a maior sanção disciplinar estabelecida pela LOMAN, a aposentadoria compulsória. Em recurso ao STF, os ministros entenderam que não haveria provas de que a juíza conhecia as condições da cela na qual a adolescente se encontrava. Ainda assim, o STF determinou reavaliação do caso pelo CNJ. Apenas em outubro de 2016, o CNJ decidiu rever a punição à juíza, afastando-a da magistratura por dois anos, mantendo seus vencimentos. Após esse período, a magistrada pôde retomar a função. Ou seja, nove anos após o ocorrido, a punição estabelecida foi um tipo de "licença remunerada", considerada, entretanto, "desproporcional” pela AMB, que saiu em sua defesa $(G 1,2016)$.

Comparativamente, em nenhum ano o CNJ aplicou tantas sanções quanto o CNMP. Vale destacar dois dados. Primeiro, em onze anos, apenas cinco demissões ocorreram - destas, quatro referem-se ao mesmo PAD. Em segundo lugar, quase $45 \%$ dos casos (67 de 155) referem-se a aposentadorias compulsórias, o que significa que o servidor punido parou de trabalhar, mas continuou recebendo remuneração equivalente ao salário.

Quando analisamos o número de processos distribuídos por ano no CNJ, os dados sobre punições tornam-se insignificantes.

\footnotetext{
${ }^{12}$ Apenas com base nesses dados, não é possível afirmar as razões dessa diferença. Pode-se conjecturar sobre o trabalho das corregedorias estaduais, que talvez deixem menos casos para o CNJ; mas as razões podem ser de outra natureza. Apenas pesquisas sobre as corregedorias estaduais podem explicar isto.
} 
RAP | Os Conselhos Nacionais de Justiça e do Ministério Público no Brasil: instrumentos de accountability?

\section{GRÁFICO 5 PROCESSOS DISTRIBUÍDOS NO CNJ POR ANO}

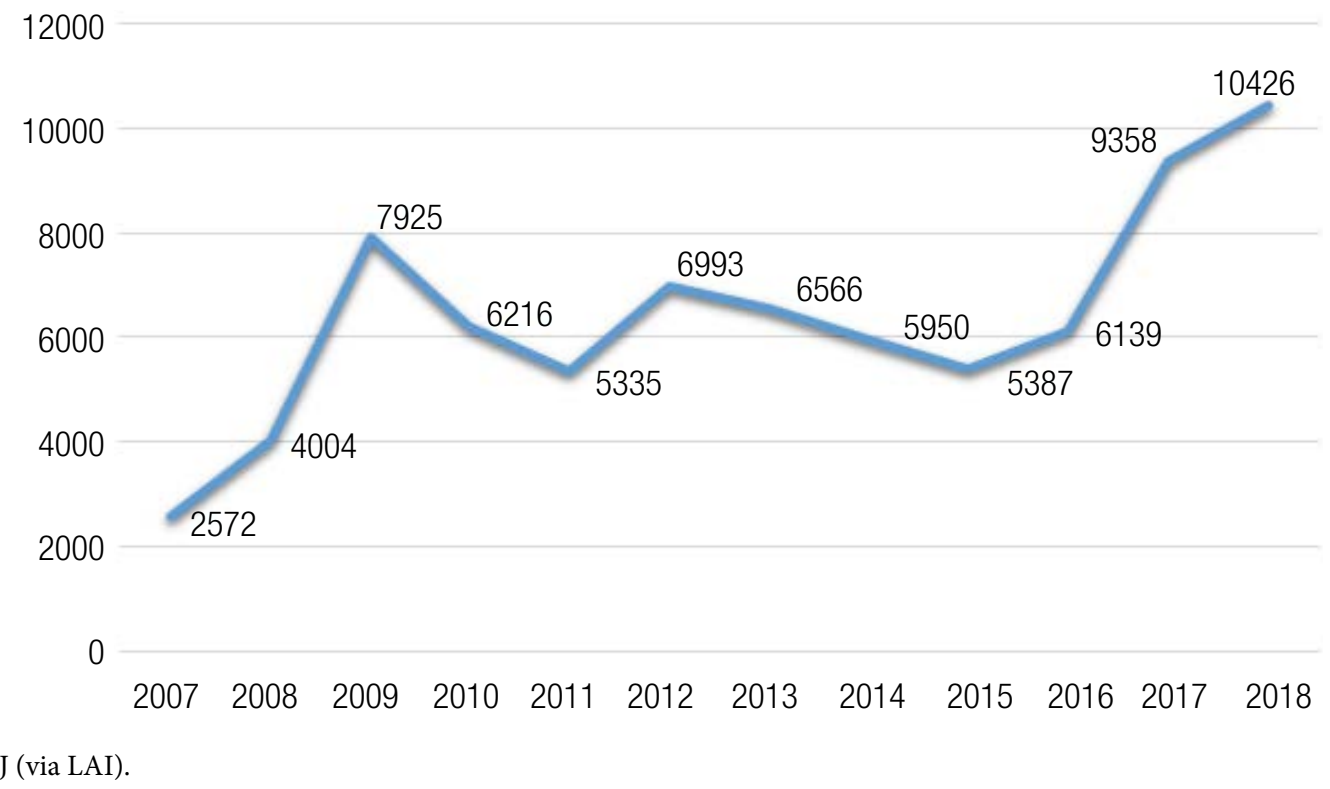

Fonte: CNJ (via LAI).

Tal como ocorre no CNMP, apesar de verificarmos um aumento no número de punições ao longo dos anos no CNJ, esse número é ínfimo perto do montante de processos distribuídos anualmente. Os dados do Gráfico 4 e do Gráfico 5, analisados conjuntamente, são apresentados na Tabela 1, apontando que menos de $0,5 \%$ dos processos distribuídos por ano leva a alguma punição.

\section{TABELA 1 PROCESSOS DISTRIBUÍDOS, PENALIDADES E PERCENTUAL ANUAL DE PENALIDADES, CNJ, 2007-2018}

\begin{tabular}{|c|c|c|c|}
\hline & Total distribuído & Punições & $\%$ punições por ano \\
\hline 2007 & 2.572 & 0 & $0,00 \%$ \\
\hline 2008 & 4.004 & 3 & $0,07 \%$ \\
\hline 2009 & 7.925 & 5 & $0,06 \%$ \\
\hline 2010 & 6.216 & 25 & $0,40 \%$ \\
\hline 2011 & 5.335 & 6 & $0,11 \%$ \\
\hline 2012 & 6.993 & 14 & $0,20 \%$ \\
\hline 2013 & 6.566 & 19 & $0,29 \%$ \\
\hline 2014 & 5.950 & 6 & $0,10 \%$ \\
\hline 2015 & 5.387 & 5 & $0,09 \%$ \\
\hline 2016 & 6.139 & 9 & $0,15 \%$ \\
\hline 2017 & 9.358 & 14 & $0,15 \%$ \\
\hline 2018 & 10.426 & 7 & $0,07 \%$ \\
\hline
\end{tabular}

Fonte: CNJ (via LAI). 
Tanto no CNJ quanto no CNMP, obter a punição de um promotor ou de um juiz por sua atuação é uma tarefa inglória. No caso do CNJ, a média anual de punições entre 2007 e 2018 é de 0,14\%. Ou seja, pouquíssimo do que chega ao Conselho se transforma em punições. Trabalhos que explorem as (não) penalizações possibilitarão uma compreensão mais acurada do que é de fato (ou não) punido, assim como o grau de (in)adequação das decisões. Parece-nos pouco provável, contudo, que a ínfima proporção de menos de meio por cento das denúncias seja de fato procedente.

Enfim, se a criação dos Conselhos Nacionais do Judiciário e do MP incrementaram os controles internos, a accountability democrática propriamente dita continua ausente. Em vez de transparência, há opacidade, os Conselhos são formados, em sua maioria, por membros internos ao Judiciário e ao MP. As punições são poucas e brandas, reforçando não só a independência das instituições judiciais, mas seu insulamento e a baixa accountability de seus integrantes. Tal insulamento burocrático pode ser lido como uma deficiência do sistema de controles (Cavalcante, Lotta, \& Oliveira, 2018).

\section{CONSIDERAÇÕES FINAIS}

Desde a redemocratização, os países latino-americanos passaram por significativos processos de reforma de suas instituições estatais, em alguns casos por meio de novas constituições, noutros por transformação das normas constitucionais vigentes ou pela aprovação de uma legislação infraconstitucional. Dentre as diversas mudanças importantes, figura a transformação das instituições judiciais e a criação de conselhos de justiça (Hammergren, 2002; Pozas-Loyo \& Ríos-Figueroa, 2010, 2010a). Essa reformulação, que deu origem aos novos órgãos, teve motivações diversas, como conferir maior independência aos atores judiciais, empoderando-os (Finkel, 2008), aprimorar o processo de seleção de magistrados (Hammergren, 2002), ou criar mecanismos mais efetivos de supervisão e controle dos juízes pelas supremas cortes (Pozas-Loyo \& Ríos-Figueroa, 2010a).

No caso brasileiro, dois debates caminharam juntos: o reforço da independência das instituições judiciais e a criação de instrumentos para sua responsabilização. O reforço institucional e o ganho de independência do Judiciário e do MP (em especial deste último) desenvolveram-se desde meados dos anos 80, com especial impulso durante a Constituinte, quando foram criadas novas estruturas judiciárias, como o Superior Tribunal de Justiça, e se transformou o MP numa espécie de quarto Poder do Estado (Arantes, 2011; Arantes \& Moreira, 2019; Kerche, 2009, 2014, 2018). Contudo, embora a questão da responsabilização dos atores judiciais já tenha surgido à época da Constituinte, a sua institucionalização não prosperou devido à própria capacidade que tiveram esses atores de antes se empoderar que permitir a criação de instrumentos para seu controle, seja no âmbito interno, seja sobretudo - por meio de alguma forma de controle externo (Fragale, 2013; Nunes, 2010; Ribeiro \& Arguelhes, 2015; Ribeiro \& Paula, 2016).

Apesar disso, o debate sobre um controle externo das instituições judiciais permaneceu aceso e levou alguns a esperar que ele pudesse advir da reforma do Judiciário promovida pelo governo Lula em 2004. Isso novamente não ocorreu, embora tenham-se instituído nesta reforma, pela Emenda Constitucional n. 45 (2014), dois conselhos destinados ao controle interno de juízes e promotores - o CNJ e o CNMP. Se alguns ainda nutriam a expectativa de que tais Conselhos pudessem ser instrumentos efetivos de accountability democrática - ou seja, de algum tipo de controle externo dos atores judiciais -, ela se frustrou. A reforma incorporou muito do que já vinha sendo discutido no 
período precedente e o acordo possível era em torno de instrumentos de accountability administrativa - ou seja, de controle interno (Fragale, 2013; Ribeiro \& Paula, 2016; Ribeiro \& Arguelhes, 2015).

Vale notar que houve um papel importante do STF na definição dos reais poderes e competências dos Conselhos, quando decidiu sobre o caso do CNJ. De certa forma, em conformidade com o que observam Arantes e Moreira (2019), não foi o legislador, mas a corte que definiu as fronteiras de atuação de um órgão do sistema de Justiça - neste caso, de seu órgão de controle interno. Ou seja, os limites do controle sobre os atores judiciais foram estipulados por eles mesmos - e não por agentes externos democraticamente legitimados, como o Congresso.

Juízes e promotores têm-se mostrado fortes o bastante para resistir a quaisquer formas mais amplas de controle que ultrapassem aquele exercido por seus próprios pares e no interior de suas organizações. Não se trata apenas de impedir que órgãos de controle externo sejam criados, mas também de manter uma legislação disciplinar que é consideravelmente generosa no que diz respeito às penalidades aplicadas aos transgressores - como no caso da LOMAN, que torna a aposentadoria compulsória a mais severa punição cabível a juízes vitalícios no âmbito administrativo. Um sistema mais efetivo de accountability requereria não só estruturas organizacionais com maior capacidade de controlar a conduta de atores do sistema de justiça, integradas por mais membros externos a corporações. Também seriam necessárias normas legais que facultassem a essas estruturas (até mesmo àquelas já existentes) a penalização mais severa de transgressões.

A falta de uma maior responsabilização e de punições mais severas dos atores judiciais por transgressões diversas torna-os parte de um grupo social diferenciado dentro do Estado brasileiro, dotado de proteções e benefícios inacessíveis a outros servidores públicos e, sobretudo, aos cidadãos comuns. A baixa efetividade dos instrumentos de sanção revela-se tanto nos números implausivelmente modestos de punições, sobretudo no caso do CNJ (conforme mostramos nos dados), como também nas penas pouco rigorosas. $\mathrm{O}$ fato de alguma alteração do padrão ser observada com a mudança do perfil de um ator-chave, tal qual o corregedor (veja-se o caso de Eliana Calmon), demonstra que não são apenas as normas que levam à pouca capacidade dissuasória dos comportamentos inaceitáveis, mas também as escolhas feitas dentro da latitude decisória disponível. Ou seja, o insulamento e a autoproteção corporativa não decorrem apenas de regras lenientes (embora também delas), mas de decisões nesse sentido, continuadamente tomadas pelos membros do MP e do Judiciário no exercício do controle de seus próprios pares. Isso faz com que não apenas seja difícil inibir ações politizadas de atores judiciais, que buscam a consecução de agendas próprias (Oliveira \& Couto, 2019), como outros comportamentos que seriam impróprios não apenas a juízes e promotores, dos quais se espera comedimento político, mas a qualquer servidor público, ou mesmo a qualquer cidadão, de quem se espera apenas o cumprimento da lei e de suas obrigações funcionais. 


\section{REFERÊNCIAS}

Aaken, A. V., Feld, L. P., \& Voigt, S. (2010). Do independent prosecutor deter political corruption? An empirical evaluation across seventy-eight countries. American Law and Economics Review, 12(1), 204-244.

Arantes, R. B. (2011). The Federal Police and the Ministério Público. In T. Power, \& M. Taylor. (Org.), Corruption and democracy in Brazil (pp. 184-217). Notre Dame, IN: University of Notre Dame Press.

Arantes, R. B., \& Moreira, T. M. (2019). Democracia, instituições de controle e justiça sob a ótica do pluralismo estatal. Opinião Pública, 25(1), 97-135.

Bovens, M., Goodin, R., \& Schillmans, T. (Ed.). (2014). The Oxford handbook of public accountability. Oxford, UK: Oxford University Press.

Brígido, C. (2016, 09 de março). STF anula nomeação de Wellington César no Ministério da Justiça. $O$ Globo. Recuperado de https://oglobo.globo.com/ brasil/stf-anula-nomeacao-de-wellington-cesar-noministerio-da-justica-18838623

Calvert, R. L., McCubbins, M. D., \& Weingast, B. R. (1989). A theory of political control and agency discretion. American Journal of Political Science, 33(3), 588-611.

Cardoso, C. (2004, 10 de abril). Por um Ministério Público Republicano. Folha de S. Paulo. Recuperado de https://wwwl.folha.uol.com.br/fsp/opiniao/ fz1004200410.htm

Carvalho, E. (2006). O controle externo do Poder Judiciário: o Brasil e as experiências dos Conselhos de Justiça na Europa do Sul. Revista de Informação Legislativa, 43(170), 99-109.

Carvalho, E., \& Leitão, N. (2013). O poder dos juízes: Supremo Tribunal Federal e o desenho institucional do Conselho Nacional de Justiça. Revista de Sociologia e Política, 21(45), 13-27.

Cavalcante, P., Lotta, G., \& Oliveira, V. E. (2018). Do insulamento burocrático à governança democrática: as transformações institucionais e a burocracia no Brasil. In R. Pires, G. Lotta, \& V. E. Oliveira. (Eds.), Burocracia e Políticas Públicas no Brasil: interseç̧ões analíticas (pp. 59-83). Brasília, DF: IPEA.

Clark. T. S. (2011). The limits of judicial independence. New York, NY: Cambridge University Press.
Consultor Jurídico. (2016, 02 de março). CNMP nega liminar e permite que procurador assuma Ministério da Justiça. Recuperado de https://www.conjur.com. br/2016-mar-02/cnmp-nega-liminar-permiteposse-ministro-justica

Consultor Jurídico. (2017, 04 de abril). OAB elege representantes da advocacia no CNMP e no CNJ. Recuperado de https://www.conjur.com.br/2017abr-04/oab-elege-representantes-advocacia-cnmp-cnj Consultor Jurídico. (2017a, 11 de setembro). Regra que permite ao MP ignorar ação penal gera controvérsias. Recuperado de https://www.conjur. com.br/2017-set-11/regra-permite-mp-ignoraracao-penal-gera-controversias

Consultor Jurídico. (2017b, 28 de agosto). Corregedoria Nacional de Justiça recebeu 7,6 mil processos nos últimos 12 meses. Recuperado de https:// www.conjur.com.br/2017-ago-28/corregedorianacional-justica-recebeu-76-mil-acoes-ano

Conselho Nacional de Justiça. (2020). Portal CNJ. Recuperado de https://www.cnj.jus.br

Conselho Nacional de Justiça. (2020a). Composição Atual. Recuperado de https://www.cnj.jus.br/ composicao-atual/

Conselho Nacional de Justiça. (2020b). Composições Anteriores. Recuperado de https://www.cnj.jus.br/ sobre-o-cnj/composicoes-anteriores/

Conselho Nacional do Ministério Público. (2017, 06 de abril). CNPG e OAB definem indicados para os cargos de conselheiro do CNMP. Recuperado de https://www.cnmp.mp.br/portal/todas-asnoticias/10218-cnpg-e-oab-definem-indicadospara-os-cargos-de-conselheiro-do-cnmp

Constituição da República Federativa do Brasil de 1988. (1988). Brasília, DF. Recuperado de http://www.planalto.gov.br/ccivil_03/constituicao/ constituicao.htm

Dahl, R. A. (1982). Dilemmas of pluralist democracy: autonomy vs. control. New Haven, CT: Yale University Press.

Emenda Constitucional n.45, de 30 de dezembro de 2004. (2004). Altera dispositivos dos arts. $5^{\circ}, 36,52$, 92, 93, 95, 98, 99, 102, 103, 104, 105, 107, 109, 111, $112,114,115,125,126,127,128,129,134$ e 168 da Constituição Federal, e acrescenta os arts. 103-A, 
103B, 111-A e 130-A, e dá outras providências. Brasília, DF. Recuperado de http://www.planalto.gov. br/ccivil_03/constituicao/Emendas/Emc/emc45.htm

Emenda Constitucional $n$. 61, de 11 de novembro de 2009. (2009). Altera o art. 103-B da Constituição Federal, para modificar a composição do Conselho Nacional de Justiça. Brasília, DF. Recuperado de http://www.planalto.gov.br/ccivil_03/constituicao/ Emendas/Emc/emc61.htm

Enciclopédia Pública da PUCSP. (2017, abril). Tomo Direito Administrativo e Constitucional (Edição 1). São Paulo, SP: Conselho Nacional do Ministério Público. Recuperado de https://enciclopediajuridica. pucsp.br/verbete/69/edicao-1/conselho-nacionaldo-ministerio-publico

Finkel, J. (2008). Judicial reform as political insurance. Notre Dame, IN: University of Notre Dame Press.

Fionda, J. (1995). Public prosecutors and discretion: a comparative study. Oxford, UK: Claredon Press.

Fragale, R., Filho. (2013). Conselho Nacional de Justiça: desenho institucional, construção de agenda e processo decisório. Dados, 56(4), 975-1007.

G1. (2016, 12 de outubro). Juíza do PA que manteve menina em cela masculina é punida pelo CNJ. Recuperado de http://g1.globo.com/pa/para/ noticia/2016/10/juiza-do-pa-que-manteve-meninaem-cela-masculina-e-punida-pelo-cnj.html

Garoupa, N., \& Ginsburg, T. (2008). Guarding the guardians: judicial councils and judicial independence (John M. Olin Program in Law and Economics Working Paper n. 444). Chicago, IL; University of Chicago Law School.

Guarnieri, C. (2015). The courts. In E. Jones, \& G. Pasquino. (Eds.), The Oxford handbook of Italian politics (pp. 120-132). Oxford, UK: Oxford University Press.

Haidar, R. (2012). CNJ pode processar juízes antes das corregedorias. Consultor Jurídico. Recuperado de https://www.conjur.com.br/2012-fev-02/cnj-abrirprocessos-juizes-fundamentar-decisao

Hammergren, L. (2002, junho). Do judicial councils further judicial reform. Lessons from Latin America (Rule of Law Series, 28). Washington, D.C.: Carnegie Endowment for International Peace.
Kerche, F. (2009). Virtude e limites: autonomia e atribuições do Ministério Público no Brasil. São Paulo, SP: Edusp.

Kerche, F. (2014). O Ministério Público no Brasil: relevância, características e uma agenda para o futuro. Revista USP, 101, 113-120.

Kerche, F. (2018). Independência, Poder Judiciário e Ministério Público. Caderno CRH, 31(84), 567-580.

Kerche, F., \& Marona, M. (2018). O Ministério Público na Operação Lava Jato: como eles chegaram até aqui? In F. Kerche, \& J. Feres Jr. (Coord.), Operação Lava Jato e a democracia brasileira (pp. 69-100). São Paulo, SP: Ed. Contracorrente.

Lei Complementar 35, de 14 de março de 1979. (1979). Dispõe sobre a Lei Orgânica da Magistratura Nacional. Brasília, DF. Recuperado de http://www. planalto.gov.br/ccivil_03/leis/lcp/lcp35.htm

Lei n. 12.850 de 2 de agosto de 2013. (2013). Define organização criminosa e dispõe sobre a investigação criminal, os meios de obtenção da prova, infrações penais correlatas e o procedimento criminal; altera o Decreto-Lei no 2.848, de 7 de dezembro de 1940 (Código Penal); revoga a Lei $n^{\circ} 9.034$, de 3 de maio de 1995; e dá outras providências. Brasília, DF. Recuperado de http://www.planalto.gov.br/ ccivil_03/_ato2011-2014/2013/lei/112850.htm

Lima, L. G. M. (2017). As medidas de natureza disciplinar no âmbito do Conselho Nacional do Ministério Público (CNMP). Revista Jurídica Corregedoria Nacional, 3, 11-33.

Limongi, F. (2006). A democracia no Brasil: presidencialismo, coalizão partidária e processo decisório. Novos Estudos/Cebrap, 76, 17-41.

Maravall, J. M. (2003). The rule of law as a political weapon. In B. Manin, \& A. Przeworski. (Ed.), Democracy and the rule of law (pp. 261-301). Cambridge, UK: Cambridge University Press.

Melton, J., \& Ginsburg, T. (2014, Fall). Does de jure judicial independence really matter? (Coase-Sandor Institute for Law \& Economics Working Paper No. 612). Chicago, IL: University of Chicago Law School.

Nunes, R. M. (2010). Politics without insurance: democratic competition and Judicial Reform in Brazil. Comparative Politics, 42(3), 313-331. 
Oliveira, V. E., \& Couto, C. G. (2019). Politização da justiça: atores judiciais têm agendas próprias? Cadernos Adenauer, 1, 139-162.

Pessanha, C. (2013). Controle do Judiciário: o Conselho Nacional de Justiça. In L. Avritzer, N. Bignotto, F. Filgueiras, \& J. Starling (Org.), Dimensões políticas da justiça (pp. 505-511). Rio de Janeiro, RJ: Civilização Brasileira.

Pessanha, C. (2014). A experiência dos Conselhos de Magistratura ibero-americanos: uma análise comparativa entre Portugal, Espanha, Argentina e Brasil. In Anais do $9^{\circ}$ Encontro da ABCP, Brasília, DF.

Poulsen, B. (2009). Competing traditions of governance and dilemmas of administrative accountability: the case of Denmark. Public Administration, 87(1), 117-131.

Pozas-Loyo, A., \& Ríos-Figueroa, J. (2010). Enacting constitutionalism: the origins of independent judicial institutions in Latin America. Comparative Politics, 42(3), 293-311.

Pozas-Loyo, A., \& Ríos-Figueroa, J. (2010a). The politics of amendment processes: Supreme Court influence in the design of Judicial Councils. Texas Law Review, 89(1), 1807-1833.

Resolução no 13, de 02 de outubro de 2006. (2006). Regulamenta o art. $8^{\circ}$ da Lei Complementar 75/93 e o art. 26 da Lei n. ${ }^{\circ} 8.625 / 93$, disciplinando, no âmbito do Ministério Público, a instauração e tramitação do procedimento investigatório criminal, e dá outras providências. Recuperado de https://www.cnmp.mp.br/portal/atos-enormas/norma/430/\#: :text=Regulamenta $\% 20$ o\%20art.,criminal\%2C\%20e\%20d\%C3\%A1\%20 outras\%20provid\%C3\%AAncias

Regimento Interno do Conselho Nacional do Ministério Público. (2020). Atualizado até a Emenda Regimental n. 28, 15 de julho de 2020. Brasília, DF. Recuperado de https://www.cnmp.mp.br/portal/ images/Regimento_Interno/Regimento_Interno_ do_CNMP_2020_agosto.pdf

Ribeiro, L. M., \& Arguelhes, D. W. (2015). O Conselho no Tribunal: mudança institucional e a judicialização de decisões do CNJ junto ao Supremo Tribunal Federal. Revista Direito e Práxis, 6(12), 464-503.

Ribeiro, L. M., \& Paula, C. J. (2016). Inovação institucional e resistência corporativa: o processo de institucionalização e legitimação do Conselho
Nacional de Justiça. Revista Brasileira de Políticas Públicas, 6(3), 13-28.

Sberna, S., \& Vannucci, A. (2013). 'It's the politics, stupid!'. The politicization of anti-corruption in Italy. Crime Law Soc. Change, 60, 565-593.

Schedler, A., Diamond, L. J., \& Plattner, M. F. (Eds.). (1999). The self-restraining state: power and accountability in new democracies. Boulder, Colorado: Lynne Rienner Publishers.

Shapiro, M. (2013). Judicial independence: new challenges in stablished nations. Indiana Journal of Global Legal Studies, 20(1), 253-277.

Streck, L. L., Sarlet, I. W., \& Clève, C. M. (2005). Os limites constitucionais das resoluções do Conselho Nacional de Justiça (CNJ) e do Conselho Nacional do Ministério Público (CNMP). Revista da EMESC. Recuperado de http://www.egov.ufsc.br/portal/sites/ default/files/anexos/15653-15654-1-PB.pdf

Supremo Tribunal Federal. (2012, 08 de fevereiro). STF conclui julgamento que apontou competência concorrente do CNJ para investigar juízes. Notícias STF. Recuperado de. http://www.stf.jus.br/portal/ cms/verNoticiaDetalhe.asp?idConteudo=199645

Supremo Tribunal Federal. (2015, 14 de maio). STF fixa requisitos para atuação do Ministério Público em investigações penais. Notícias STF. Recuperado de http://www.stf.jus.br/portal/cms/ verNoticiaDetalhe.asp? idConteudo $=291563$

Supremo Tribunal Federal. (2017, 10 de novembro). Edital abre seleção para vaga de conselheiro do CNMP. Recuperado de http://www.stf.jus.br/portal/ $\mathrm{cms} /$ verNoticiaDetalhe.asp?idConteudo $=361571$

Sutherland, S. L. (1993). Independent review and political accountability: should democracy be on autopilot? Optimum: The journal of Public Sector Management, 24, 23-41.

Taylor, M. M. (2017). Judicial independence in Latin America. No Prelo.

Terquem, F. (1998). Le coup D'État Judiciaire. Paris, France: Éditions Ramsay.

Tomio, F. R. L., \& Robl, I. N., Filho. (2013). Accountability e independência judiciais: uma análise da competência do Conselho Nacional de Justiça (CNJ). Revista de Sociologia e Política, 21(45), 29-46. 
RAP | Os Conselhos Nacionais de Justiça e do Ministério Público no Brasil: instrumentos de accountability?

\section{Fábio Kerche}

https://orcid.org/0000-0002-0503-6446

Doutor em Ciência Política pela USP; Pesquisador titular da Fundação Casa de Rui Barbosa; Professor dos Programas de Pós-Graduação em Ciência Política da UNIRIO e do IERSP/UERJ. E-mail: fabio.kerche@rb.gov.br

\section{Vanessa Elias de Oliveira}

https://orcid.org/0000-0001-8916-4981

Doutora em Ciência Política pela USP; Professora Associada de Políticas Públicas da Universidade Federal do ABC (UFABC).E-mail: vanessa.oliveira@ufabc.edu.br

\section{Cláudio Gonçalves Couto}

https://orcid.org/0000-0003-0153-1877

Doutor em Ciência Política; Professor na Escola de Administração de Empresas de São Paulo da Fundação Getulio Vargas (FGV EAESP). E-mail: claudio.couto@fgv.br 